\title{
PENERAPAN MODEL COOPERATIVE LEARNING TIPE JIGSA W UNTUK MENINGKATKAN PENGUASAAN KONSEP SISWA DALAM PEMBELAJARAN IPA DI SEKOLAH DASAR
}

\author{
Nursania Azzahra, Suko Pratomo, Tati Sumiati
}

Program Studi PGSD, Universitas Pendidikan Indonesia, Kampus Purwakarta

Kata Kunci :

Penguasaan Konsep, Cooperative Learning, Jigsaw, Pembelajaran IPA
Email penulis:

wildaoktafiani@student.upi.edu

\begin{abstract}
This research was motivated by findings regarding the low activity and mastery of the concepts of students in science learning in the fifth grade of Wiwitan State Elementary School. This study aims to improve the mastery of the concepts of students in science learning in the fifth grade of Wiwitan Elementary School. The subjects in this study were fifth grade students of SD Negeri Wiwitan Academic Year 2017-2018 which numbered 25 people. The research method used is classroom action research conducted in two cycles. Each cycle consists of four stages, namely planning, implementation, observation and reflection. Data collection is done through tests, observations of student and teacher activities, interviews and documentation. Based on the results of these studies, it shows that the jigsaw type cooperative learning model is proven to be able to improve the mastery of students' concepts in science learning.
\end{abstract}

\section{PENDAHULUAN}

Sekolah merupakan suatu lembaga pendidikan formal sebagai tempat anak belajar. Hafid, dkk. (2014, hlm. 82) menyatakan bahwa "pendidikan formal terdiri dari 4 jenjang yaitu pendidikan prasekolah, pendidikan dasar, pendidikan menengah dan pendidikan tinggi". 
Menurut Ihsan (2013, hlm. 129-130) "pendidikan dasar diselenggarakan untuk mengembangkan sikap dan kemampuan serta memberikan pengetahuan dan keterampilan dasar yang diperlukan untuk hidup dalam masyarakat serta mempersiapkan peserta didik yang memenuhi persyaratan untuk mengikuti pendidikan menengah". Betapa pentingnya pendidikan dasar bagi peserta didik mengingat sikap sangatlah penting dalam kehidupan. Tak hanya itu, pengetahuan yang disertai kemampuan juga diperlukan dalam kehidupan.

Pelaksanaan kegiatan-kegiatan pendidikan dalam setiap jenjang pendidikan didasarkan pada kurikulum yang berlaku secara nasional. Seperti yang disampaikan Jufri (2017, hlm. 122) bahwa "dalam lampiran Permendikbud Nomor 58 tahun 2014 dinyatakan bahwa IPA sebagai mata pelajaran, diberikan mulai dari jenjang sekolah dasar sampai jenjang sekolah menengah atas”. Maka tugas guru adalah melaksanakan proses pembelajaran IPA.

Tentunya tidak berarti bahwa semua proses tersebut berjalan dengan lancar. Berdasarkan hasil observasi, wawancara dan hasil tes yang diberikan pada siswa kelas V SDN Wiwitan, ditemukan data sebesar $24 \%$ siswa mendapatkan nilai diatas kriteria ketuntasan minimum (KKM) pada pelajaran IPA dan sebanyak $76 \%$ dari 25 siswa belum mendapatkan nilai diatas KKM. KKM yang telah ditetapkan SDN Wiwitan untuk mata pelajaran IPA di kelas V yaitu sebesar 68,00. Temuan ini menyatakan bahwa kemampuan penguasan konsep siswa di SDN Wiwitan masih rendah. Menurut Syaodih (dalam Frisiani, 2014, hlm. 20) bahwa "penguasaan konsep lebih banyak menyangkut aspek kognitif, intelektual atau kemampuan berfikir. Oleh karena itu standar dan kriterianya lebih mengarah pada aspek-aspek kognitif. Konsep merupakan bagian utama dari ranah kognitif".

Selain itu dalam kegiatan berkelompok pada saat pembelajaran berlangsung hanya terdapat beberapa siswa saja yang aktif dalam kelompoknya. Selain itu terdapat siswa yang masih mengandalkan teman sekelompoknya sehingga kurang adanya rasa tanggung jawab dalam diri tiap anggota kelompok untuk mengikuti jalannya kegiatan berdiskusi. Seperti yang disampaikan oleh Slavin (dalam Al-Tabany, 2015, hlm. 109) bahwa "Belajar kooperatif menekankan pada tujuan dan kesuksesan kelompok, yang hanya dapat dicapai jika semua anggota kelompok mencapai tujuan atau penguasaan materi”.

Salah satu model pembelajaran kooperatif yaitu jigsaw. Menurut Hamdayama (2014, hlm. 87): "jigsaw adalah pembelajaran kooperatif yang dikembangkan oleh Elliot Aronson's (Aronson, Blaney, Stephen, Sikes, and SNAPP, 1978). Model pembelajaran ini didesain untuk meningkatkan rasa tanggung jawab siswa terhadap pembelajarannya sendiri dan juga pembelajaran orang lain. Siswa tidak hanya mempelajari materi yang diberikan, tetapi mereka juga harus siap memberikan dan mengajarkan materi tersebut kepada kelompoknya. Hal ini menyatakan pembelajaran yang dilakukan secara kooperatif akan menumbuhkan rasa tanggung jawab siswa yang diperlukan dalam pembelajaran. Rasa tanggung jawab termasuk kedalam moral". Berdasarkan uraian di atas perlu dikaji lebih jauh mengenai model cooperative learning tipe jigsaw terhadap penguasaan konsep siswa di sekolah dasar

\section{KAJIAN TEORI}

\section{Pengertian Model Cooperative Learning Tipe Jigsaw}

Menurut Majid (2013, hlm. 182) "ditinjau dari sisi etimologi, jigsaw berasal dari bahasa Inggris yang berarti gergaji ukir. Ada juga yang menyebutnya dengan istilah fuzzle, yaitu sebuah teka teki yang menyusun potongan gambar. Pembelajaran kooperatif model jigsaw ini juga mengambil pola cara bekerja sebuah gergaji (jigsaw) yaitu siswa melakukan kegiatan belajar dengan cara bekerjasama dengan siswa lain untuk mencapai tujuan 
bersama". Jadi jigsaw merupakan salah satu tipe dari pembelajaran kooperatif. Dimana siswa belajar dalam kelompok yang membutuhkan saling ketergantungan yang harus tertanam dalam setiap diri anggota tim.

\section{Model Cooperative Learning Tipe Jigsaw}

Menurut Lestari dan Yudhanegara (2017, hlm. 48-49) mengungkapkan bahwa tahapan jigsaw adalah sebagai berikut:

a. Grouping: Membagi siswa ke dalam beberapa grup yang terdiri atas 5-6 siswa yang heterogen

b. Leader: Menentukan satu orang siswa dari setiap kelompok sebagai ketua kelompok (leader). Siswa yang ditunjuk sebagai ketua merupakan siswa yang paling unggul/matang dalam kelompoknya

c. Partition: Membagi/mempartisi materi pelajaran ke dalam 5-6 subtopik. Masing-masing siswa dalam satu kelompok memilih satu subtopik yang menjadi tanggung jawabnya

d. Expert Groups: Siswa yang mendapat topik yang sama dengan siswa kelompok lain, bergabung dalam satu kelompok baru yang disebut kelompok ahli (expert group). Siswa dalam kelompok ahli ini mendiskusikan satu topik yang menjadi tanggung jawabnya dan mencatat poin-poin penting dalam topik tersebut

e. Sharing and Presentation: Setelah selesai berdiskusi, kelompok ahli kembali ke kelompok asal untuk berbagi dan mempresentasikan hasil diskusinya. Pada tahap ini, siswa saling melengkapi satu sama lain sehingga terbentuk suatu pengetahuan yang utuh terhadap materi yang dipelajari

f. Observing: Guru mengamati proses yang berlangsung pada masing-masing kelompok. Jika terdapat anggota kelompok yang mengalami kesulitan dalam menjelaskan subtopik yang menjadi tanggung jawabnya, guru memerintahkan ketua kelompok untuk membantu anggotanya tersebut

g. Quiz: Guru memberikan kuis untuk mengecek pemahaman siswa

\section{Penguasaan Konsep}

Menurut Sagala (2005, hlm.71) bahwa "konsep diperoleh dari fakta, peristiwa, pengalaman, melalui generalisasi, dan bersifat abstrak. Konsep dapat mengalami perubahan disesuaikan dengan fakta atau pengalaman baru, sedangkan kegunaan konsep adalah menjelaskan dan meramalkan". Adapun menurut Hendridunan (dalam Mawardi, 2015, hlm. 14) mendefinisikan bahwa "penguasaan konsep merupakan kemampuan siswa menguasai materi pelajaran yang diberikan". Menurut Anderson dan Krathwohl (2017, hlm. 100-102) bahwa "dimensi proses kognitif mencakup mengingat, memahami, mengaplikasikan, menganalisis, mengevaluasi, dan mencipta".

\section{Pembelajaran IPA}

Menurut Wisudawati dan Sulistyowati (2017, hlm. 26) bahwa "pembelajaran IPA adalah interaksi antara komponen-komponen pembelajaran dalam bentuk proses pembelajaran untuk mencapai tujuan yang berbentuk kompetensi yang telah di tetapkan". Sedangkan menurut Sapriati, dkk (2014, hlm. 2.3) mengungkapkan bahwa "pendidikan IPA menekankan pada pemberian pengalaman langsung untuk mencari tahu dan berbuat sehingga mampu menjelajahi dan memahami alam sekitar secara ilmiah"

\section{METODE PENELITIAN}

Metode penelitian yang digunakan adalah penelitian tindakan kelas (PTK). Desain penelitian yang akan digunakan mengacu pada model yang dikembangkan Kemmis dan MC. Taggart. Menurut Paizaluddin dan Ermalinda (2014, hlm. 30) bahwa "model yang dikembangkan oleh Stephen Kemmis dan Robin Mc Taggart tampak masih begitu dekat dengan model yang 
diperkenalkan oleh Kurt Lewin. Dikatakan demikian, oleh karena di dalam satu siklus atau putaran terdiri dari empat komponen meliputi: 1. Perencanaan (planning); 2. aksi atau tindakan (acting); 3. observasi (observing); dan 4. refleksi (reflecting)".

Penelitian tindakan kelas ini dilakukan pada kelas V SDN Wiwitan dengan jumlah subyek penelitian 25 siswa terdiri dari 11 siswa laki-laki dan 14 siswa perempuan. Di dalam pelaksanaan penelitian. Instrumen penelitian dalam penelitian ini terdiri dari lembar observasi untuk mengamati aktivitas siswa selama pembelajaran, lembar tes untuk mengukur dan mengetahui tingkat penguasaan konsep siswa setelah diterapkannya model kooperatif tipe jigsaw dalam pembelajaran IPA yang diberikan di awal (pre test) dan di akhir pembelajaran (post test) terdiri dari 5 soal pilihan ganda dan 10 soal essay, dan pedoman wawancara yang digunakan pada penelitian ini yaitu pedoman wawancara untuk subjek guru digunakan untuk mengumpulkan informasi awal mengenai kondisi akademik siswa, karakteristik siswa kelas V, dan permasalahan yang terjadi di kelas V.

Tahap selanjutnya yang harus dilakukan setelah pengumpulan data adalah menganalisis data. Setelah didapatkan skor aktivitas siswa, Untuk mengetahui persentase dari hasil observasi, dapat dianalisis menggunakan rumus sebagai berikut:

Nilai Aktivitas $=\frac{\text { Jumlah Nilai yang diperoleh }}{\text { Skor Maksimal }} \times 100 \%$

(Purwanto, 2012, hlm. 102). Untuk menghitung persentase rata-rata aktivitas secara klasikal dapat menggunakan rumus sebagai berikut:

$\mathrm{M} \%=\frac{M}{S M i} \times 100 \%$

(Astiti \& Widiana, 2017, hlm. 34)

Keterangan:

M\% = Rata-rata persentase skor aktivitas

$M \quad$ = Rata-rata skor aktivitas

Smi = Skor Maksimal Ideal

Nilai aktivitas selanjutnya dikategorikan sebagai penilaian hasil observasi dinyatakan ketuntasannya menggunakan keterangan menurut Trianto (2010, hlm. 241) yaitu:

Keterangan:

$75 \%-100 \%=$ Sangat Tinggi

$50 \%-74,99 \%=$ Tinggi

$25 \%-49,99 \%=$ Sedang

$0 \%-24,99 \%=$ Rendah

Hasil tes penguasaan konsep di olah secara keseluruhan dan pada setiap indikator yang di pakai. Untuk menghitung ketuntasan belajar siswa dapat dihitung dengan menggunakan rumus yaitu:

$$
\text { Ketuntasan Individual }=\frac{\text { Jumlah skor yang diperoleh siswa }}{\text { Jumlah skor total maksimum }} \times 100 \%
$$

(Trianto, 2011, hlm. 241)

Menurut Depdiknas (dalam Susanto, 2013, hlm. 54) mengatakan bahwa "pembelajaran dikatakan tuntas apabila telah mencapai angka $\geq 75 \%$ ". Jadi setelah diketahui nilai ketuntasan belajar setiap siswa selanjutnya dihitung nilai presentase siswa yang mendapatkan nilai mencapai kriteria ketuntasan minimun (KKM) yaitu 68 dan secara klasikal mencapai $75 \%$. 


\section{HASIL DAN PEMBAHASAN}

Berdasarkan hasil wawancara yang dilakukan dengan guru kelas V SDN Wiwitan, didapatkan informasi bahwa karakteristik siswa kelas V SD Negeri Wiwitan sangat beragam karena beda siswa beda pula karakternya. Terdapat siswa yang tergolong pandai, siswa yang kurang pandai, dan siswa yang tidak pandai. Hal ini dikarenakan tingkat kecerdasan atau intelegensi setiap siswa berbeda-beda. Masalah yang terjadi di kelas V SD Negeri Wiwitan ini lebih banyak mengarah kepada penguasaan konsep siswa terhadap materi yang dipelajari. Penguasaan konsep siswa masih tergolong rendah atau dengan kata lain tingkat penguasaan materinya rendah.

Hasil evaluasi pembelajaran IPA masih jauh dari kriteria ketuntasan belajar (KKM) yang telah ditetapkan yaitu 68 , yang berarti masih jauh dari harapan. Nilai rata-rata yang diperoleh adalah 60. Dari 25 siswa yang terdapat di kelas V, hanya 6 siswa mendapatkan nilai yang telah mencapai KKM 68. Sedangkan siswa yang belum mencapai KKM sebanyak 19 siswa.

Berdasarkan hasil tersebut, dapat disimpulkan bahwa siswa belum menguasai konsep mengenai materi IPA yang disampaikan. Pelaksanaan penelitian tindakan kelas ini terdiri dari dua siklus. Terdapat 2 pertemuan pada setiap siklusnya dengan alokasi waktu $2 \times 35$ menit. Siklus I pertemuan pertama dilaksanakan pada hari Jum'at tanggal 20 April 2018 dan pertemuan kedua dilaksanakan pada hari Sabtu tanggal 21 April 2018. Pokok bahasan pada siklus I ini mengenai peristiwa alam. Siklus II pertemuan pertama dilaksanakan pada hari Jum'at tanggal 27 April 2018 dan pertemuan kedua dilaksanakan pada hari Sabtu tanggal 28 April 2018.

Kegiatan observasi atau pengamatan dilakukan untuk menilai aktivitas siswa pada saat pembelajaran berlangsung dengan menggunakan model cooperative learning tipe jigsaw dalam pembelajaran IPA. Berikut persentase skor hasil observasi aktivitas siswa siklus I dan II dapat dilihat pada diagram 4.1 di bawah ini.

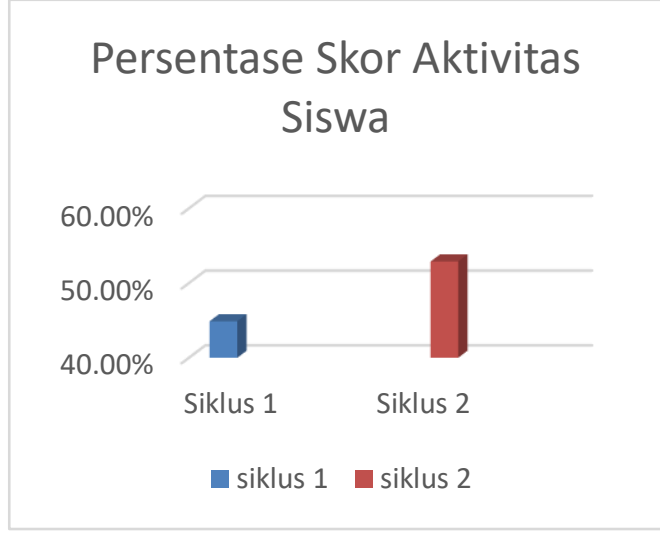

Diagram 4.1

\section{Persentase Skor Aktivitas Siswa Siklus I dan Siklus II}

Pada siklus 1 aktivitas siswa mendapat persentase skor sebesar 44,89\%, dan pada siklus II aktivitas siswa mendapat persentase skor sebesar 52,89\%. Maka telah terjadi adanya peningkatan aktivitas siswa sebesar $8 \%$. Adanya peningkatan ini membuktikan bahwa dengan menerapkan model cooperative learning tipe jigsaw, maka aktivitas siswa di dalam pembelajaranpun dapat meningkat. Sejalan dengan pendapat Sumantri (2015, hlm. 53) bahwa pembelajaran kooperatif dapat "mengembangkan keterampilan sosial, yaitu mengembangkan keterampilan sosial siswa diantaranya: berbagi tugas, aktif bertanya, 
menghargai pendapat orang lain, memancing teman untuk bertanya, mau mengungkapkan ide, dan bekerja dalam kelompok". Hal ini jelas dapat mempengaruhi aktivitas siswa pada pembelajaran di dalam kelas.

Peningkatan penguasaan konsep siswa juga dapat terlihat dari hasil tes di siklus I dan siklus II. Pada pre test siklus I diperoleh nilai rata-rata sebesar 54,64 dengan persentase ketuntasan belajar sebesar 4\%. Untuk hasil post test pada siklus I diperoleh nilai rata-rata sebesar 69,64 dengan persentase ketuntasan belajar sebesar 52\%. Dengan melihat hasil pre test dan post test pada siklus I ini telah terlihat adanya peningkatan rata-rata sebesar 15 dengan peningkatan persentase sebesar $48 \%$.

Pada pre test siklus II diperoleh rata-rata sebesar 64,96 dengan persentase ketuntasan belajar sebesar $60 \%$. Pada post test siklus II diperoleh rata-rata sebesar 76,88 dengan persentase ketuntasan belajar sebesar $88 \%$. Dengan melihat hasil pre test dan post test pada siklus II ini telah terlihat adanya peningkatan rata-rata sebesar 11,92 dengan peningkatan persentase sebesar 28\%. Supaya lebih jelas mengenai peningkatan ketuntasan belajar klasikal siswa pada siklus I dan siklus II dapat dilihat pada diagram 4.2 di bawah ini.

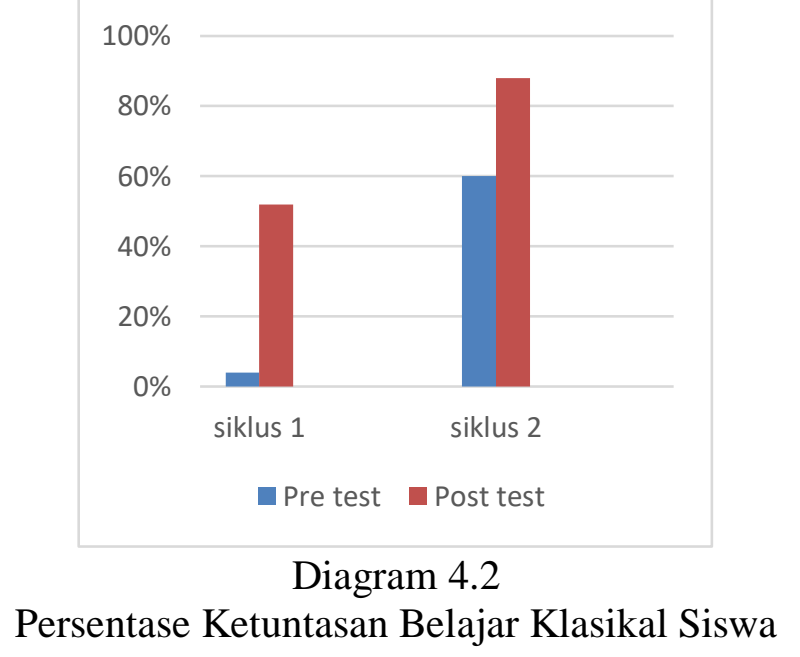

Selain melihat dari rata-rata juga persentase hasil pre test dan post test, peningkatan penguasaan konsep siswa juga dilihat dari skor gain. Skor gain yang diperoleh pada siklus I yaitu sebesar 0,33 dengan kategori sedang. Sedangkan skor gain yang diperoleh pada siklus II yaitu sebesar 0,34 dengan kategori sedang. Berikut diagram mengenai peningkatan skor gain pada siklus I dan siklus II dapat dilihat pada diagram 4.4 di bawah ini.

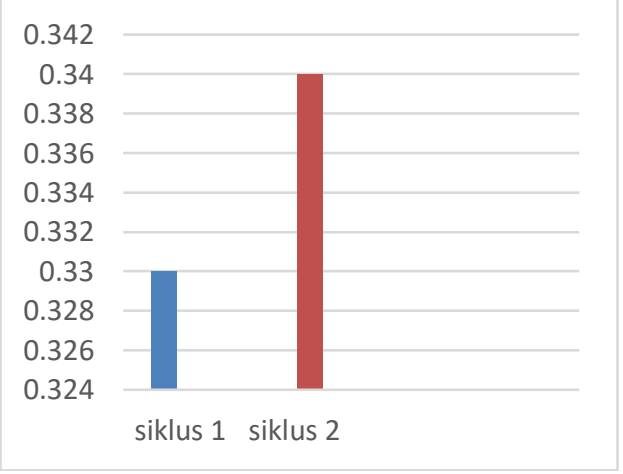

Diagram 4.4

Skor Gain Penuasan Konsep siswa Siklus I dan Siklus II 
Berdasarkan hasil yang telah diperoleh dari ketuntasan belajar dan dari peningkatan skor gain yang diperoleh dari siklus I dan siklus II terbukti bahwa dengan menerapkan model pembelajaran cooperative tipe jigsaw dapat meningkatkan penguasan konsep siswa dalam pembelajarn IPA di kelas V SD Negeri Wiwitan.

Peningkatan penguasaan konsep pada penelitian ini dipengaruhi juga dengan penggunaan model pembelajaran yang tepat. Hal ini karena dalam model kooperatif jigsaw siswa diberi tangung jawab terhadap materi yang menjadi tanggung jawabnya juga terhadap pembelajaran temannya. Sesuai dengan pendapat Sumantri (2015, hlm. 53) bahwa pembelajaran kooperatif bertujuan pada "hasil belajar akademik, meningkatkan kinerja siswa dalam tugas-tugas akademik. Pembelajaran model ini dianggap unggul dalam membantu siswa dalam memahami konsep-konsep yang sulit". Oleh karena itu penguasaan konsep siswa dapat meningkat.

\section{KESIMPULAN}

Berdasarkan hasil penelitian yang telah dilakukan, didapatkan kesimpulan sebagai berikut:

1. Berdasarkan hasil observasi terhadap aktivitas siswa selama pembelajaran menggunakan model cooperative learning tipe jigsaw, aktivitas siswa mengalami peningkatan. Pada siklus I diperoleh aktivitas siswa dengan kategori sedang dan di siklus II diperoleh aktivitas siswa dengan kategori tinggi. Pada saat kegiatan pembelajaran, siswa melakukan setiap tahap dari model cooperative learning tipe jigsaw. Dimulai dari grouping, leader, partition, expert group, sharing and presentation dan tahap terakhir yaitu quiz. Dengan pembelajaran kooperatif, siswa dapat berbagi informasi, aktif dalam bertanya, bekerja sama dalam mempelajari materi juga menyelesaikan tugas kelompoknya. Dengan demikian siswa dapat memaksimalkan belajarnya dan dapat berdampak baik terhadap penguasaan konsep materinya.

2. Telah terjadi peningkatan penguasaan konsep siswa setelah diterapkannya model cooperative learning tipe jigsaw. Dibuktikan dari peningkatan perolehan data di setiap siklusnya. Pada siklus I diperoleh data penguasaan konsep siswa dengan persentase sebesar 52\% dengan rata-rata nilai siswa 69,64. Pada siklus II diperoleh data penguasaan konsep siswa sebesar $88 \%$ dengan rata-rata nilai siswa 76,88 .

Dengan demikian dapat disimpulkan bahwa penerapan model cooperative learning tipe jigsaw dapat meningkatkan aktivitas dan penguasaan konsep siswa kelas $\mathrm{V}$ dalam pembelajaran IPA di SD Negeri Wiwitan.

\section{REFERENSI}

Anderson, L. W dan Krathwohl, D. R. (2017). Kerangka Landasan Untuk Pembelajaran, Pengajaran, dan Asesmen.Yogyakarta: Pustaka Pelajar

Al-Tabany, T. I. B. (2015). Mendesai Model Pembelajaran Inovatif, Progresif, dan Kontekstual. Jakarta: Prenadamedia Group.

Astiti \& Widiana. W. (2017). Penerapan Metode Pembelajaran Jigsaw Sebagai Upaya Meningkatkan Hasil Belajar IPA pada Siswa Kelas IV SD. Jurnal Ilmiah Sekolah Dasar, 1 (1). 30-41. https://eprints.uns.ac.id/12445/1/1418-3153-1-SM.pdf

Frisiani, H. (2014). Penerapan Model Visual Auditory Kinestetic (VAK)Untuk Meningkatkan Penguasaan Konsep Materi Struktur Bumi pada Pembelajaran IPA. UPI: Tidak Diterbitkan.

Hafid, A. dkk. (2014). Konsep Dasar Ilmu Pendidikan. Bandung: Alfabeta. 
Hamdayama, J. (2014). Model dan Metode Pembelajaran Kreatif dan Berkarakter. Bogor: Ghalia Indonesia.

Ihsan, F. (2013). Dasar-Dasar Kependidikan. Jakarta: PT. Rineka Cipta.

Jufri, W. (2017). Belajar dan Pembelajaran SAINS. Bandung: Pustaka Reka Cipta.

Lestari, K.E dan Yudhanegara, M, R. (2015). Penelitian Pendidikan Matematika. Bandung: PT Refika Aditama.

Majid, A. (2013). Strategi Pembelajaran. Bandung: PT Remaja Rosdakarya.

Mawardi, F. E. (2015). Pengaruh model Cooperative Learning Tipe Make A Match Dalam Meningkatkan Penguasaan Konsep Siswa SD. UPI Purwakarta: Tidak diterbitkan.

Paizaluddin, dan Ermalinda.(2014). Penelitian Tindakan Kelas (Classroom Action Research) Panduan Teoritis dan Praktis. Bandung: Alfabeta.

Purwanto, N. (2012). Prinsip-Prinsip dan Evaluasi Pengajaran. Bandung: PT. Remaja Rosdakarya.

Sagala, S. (2005). Konsep dan Makna Pembelajaran. Bandung: CV. Alfabeta

Sapriati, dkk. (2014). Pembelajaran IPA di SD. Tangerang Selatan: Universitas Terbuka.

Sumantri, M. S. (2015). Strategi Pembelajaran Teori dan Praktik di Tingkat Pendidikan Dasar. Jakarta: PT Rajagrafindo Persada

Susanto, A. (2013). Teori Belajar dan Pembelajaran di Sekolah Dasar. Jakarta: Kencana.

Trianto. (2010). Mendesain Model Pembelajaran Inovatif Progresif: Konsep, Landasan dan Implementasinya pada Kurikulum Tingkat Satuan Pendidikan (KTSP). Jakarta: Kencana Prenada Media Group.

Trianto. (2011). Panduan Lengkap Penelitian Tindakan Kelas.Jakarta: Prestasi Putakarya Trianto. (2010). Mendesain Model Pembelajaran Inovatif Progresif: Konsep, Landasan dan Implementasinya pada Kurikulum Tingkat Satuan Pendidikan (KTSP). Jakarta:

Kencana Prenada Media Group. 